\title{
ZAŠTITA PRAVA VLASNIŠTVA U POSTUPCIMA PROVEDBE PROSTORNIH PLANOVA
}

Antun Žagar, dipl. iur.*

\author{
UDK: $349.44: 347.232 .1$ \\ https://doi.org/10.30925/zpfsr.39.1.23 \\ Ur.: 15. siječnja 2018. \\ Pr.: 8. ožujka 2018. \\ Stručni rad
}

\begin{abstract}
Sažetak
Prostorno uređenje je multidisciplinarna djelatnost koja se u pravni život uvodi donošenjem prostornih planova te potom podvođenjem konkretnog pravnog odnosa pod mjerodavnu prostornoplansku normu, odnosno izdavanjem pojedinačnih akata za provedbu prostornih planova: lokacijske odnosno građevinske dozvole, dozvole za promjenu namjene i uporabu građevine, rješenja o utvrđivanju građevne čestice i potvrde parcelacijskog elaborata. $U$ novije su se vrijeme u postupcima provedbe prostornih planova pojavila neka pitanja na koja do tada nije bilo odgovora, odnosno nije bilo odgovora koji bi bili u skladu sa suvremenim poimanjem prava vlasništva i prava na mirno uživanje vlasništva. Predmet je ovoga rada pokušati odgovoriti na pitanje ima li u postupcima provedbe prostornih planova, ponajprije u postupcima izdavanja lokacijskih dozvola radi izgradnje infrastrukturnih objekata, mjesta zaštiti prava i interesa vlasnika zemljišta ili se u tim postupcima mora prihvatiti svaki zahtjev koji je u skladu s prostornoplanskom dokumentacijom. Zaključuje se da se, uvažavajući ciljeve i načela prostornog uređenja te načelo socijalne vezanosti vlasništva, prava i interesi vlasnika štite u određenoj mjeri.
\end{abstract}

Ključne riječi: zaštita prava vlasništva, prostorno uređenje, prostorni planovi, akti provedbe prostornih planova, lokacijska dozvola.

\section{1. $U V O D$}

Prostorno uređenje je ljudska djelatnost kojom čovjek ispunjava neke od svojih osnovnih životnih potreba i ostvaruje težnju da svijet koji ga okružuje prilagodi sebi. Zakon o prostornom uređenju, kao ni ranije važeći zakoni, ne definira pojam prostornog uređenja, već propisuje da se prostornim uređenjem osiguravaju uvjeti za korištenje, gospodarenje, zaštitu i upravljanje prostorom Republike Hrvatske te zaštićenim ekološko-ribolovnim pojasom i epikontinentalnim pojasom Republike Hrvatske kao osobito vrijednim i ograničenim nacionalnim dobrom, te da se time ostvaruju pretpostavke za društveni i gospodarski razvoj, zaštitu okoliša i prirode, vrsnoću gradnje i racionalno korištenje prirodnih i kulturnih dobara. ${ }^{1}$

* Antun Žagar, dipl. iur., sudac Upravnog suda u Rijeci; antun.zagar@usri.pravosudje.hr.

1 Čl. 2. Zakona o prostornom uređenju, NN, br. 153/13., 65/17., dalje: ZPU. 
Prostorno uređenje složen je proces koji započinje prostornim planiranjem, koje je već samo po sebi interdisciplinarna djelatnost, ${ }^{2}$ a nastavlja se usvajanjem prostornih planova političkim odlučivanjem u predstavničkim tijelima i završava provođenjem planova pojedinačnim aktima. U pravni život se prostorno uređenje uvodi donošenjem prostornih planova, koji su po svojoj prirodi opći normativni akti, te potom podvođenjem konkretnoga pravnog odnosa pod mjerodavnu prostornoplansku normu, odnosno izdavanjem pojedinačnih akata za provedbu prostornih planova, od kojih je, barem prema dojmu autora, u nas najzastupljenija lokacijska dozvola.

Ako bi se pravo prostornog uređenja definiralo kao skup pravnih pravila kojima je uređena djelatnost prostornog uređenja, onda je to svakako dio upravnog prava, ali dio upravnog prava koje zadire i u imovinskopravne odnose subjekata.

Nesumnjivo je da se na interese vlasnika zemljišta već uvelike utječe donošenjem prostornih planova. Sigurno je da će vlasnik zemljišta u urbanom gradskom području gdje je cijena građevinskog zemljišta visoka biti itekako zainteresiran koja će namjena njegovog zemljišta biti određena prostornim planom, primjerice hoće li to biti građevinsko zemljište, koje opet može biti predviđeno za izgradnju građevina stambene, poslovne, proizvodne, zdravstvene ili neke druge namjene, ili će mu zemljište biti određeno zaštitnom zelenom površinom gdje nikakva gradnja nije dopuštena. U slučaju da se u urbanom području vrijednoga građevinskog zemljišta onemogući svaka gradnja, vlasnik će, može se slobodno reći, u ekonomskom smislu biti pogođen kao da mu je zemljište oduzeto.

Imovinsko pravo se kao dio privatnog prava razvija kroz zakonodavstvo, pravnu znanost i praksu već više od dvije tisuće godina, od vremena klasičnog rimskog prava, velikih kodifikacija na prijelazu u dvadeseto stoljeće, pa sve do današnjih dana, gdje je i Hrvatska dugo dijelila kontinentalnoeuropsku pravnu tradiciju ${ }^{3}$, koju smo nakon razilaženja sa socijalističkim pravnim uređenjem ponovno preuzeli te do sada razvili bogatu i vrijednu pravnu znanost, stoga o vlasničkim tužbama, dosjelosti ili smetanju posjeda danas znamo mnogo. Međutim, u sferi reguliranja imovinskopravnih odnosa pravilima upravnog prava još uvijek ima područja gdje nema jasnih odgovora na mnoga pitanja, a isto tako i u području prava prostornog uređenja gdje nemamo nekakve bitne pravne tradicije koja bi i danas bila aktualna, a znanstvenih i stručnih radova je malo. Na pravo prostornog uređenja, kao i na sve druge grane prava $u$ nas, najprije je utjecala promjena društvenog uređenja ${ }^{4}$ te potom $\mathrm{u}$ manjem opsegu

2 Prema čl. 3. st. 1. t. 26. ZPU-a prostorno planiranje kao interdisciplinarna djelatnost je institucionalni i tehnički oblik za upravljanje prostornom dimenzijom održivosti, kojom se na temelju procjene razvojnih mogućnosti u okviru zadržavanja osobnosti prostora, zahtjeva zaštite prostora, te očuvanja kakvoće okoliša i prirode, određuje namjena prostora/površina, uvjeti za razvoj djelatnosti i infrastrukture te njihov razmještaj u prostoru, uvjeti za urbanu preobrazbu i urbanu sanaciju izgrađenih područja te uvjeti za ostvarivanje planiranih zahvata u prostoru.

3 Više o tome: Gavella, N. i dr., Teorijske osnove građanskog prava-Građansko pravo i pripadnost hrvatskog pravnog poretka kontinentalnoeuropskom pravnom krugu, Zagreb, Pravni fakultet, 2005.

4 Tu su prema našem mišljenju na imovinskopravne odnose u prostornom uređenju najviše utjecale promjene u stvarnopravnom uređenju, posebno ukidanje dualizma općih uređenja pripadanja stvari i ukidanja društvenog vlasništva te ponovno uspostavljanje pravnog jedinstva 
pristupanje europskim integracijama. Uz to se ubrzano mijenja i priroda oko nas, kao i svijest o njezinom očuvanju. Sve su to razlozi zbog kojih se mora prilagođavati i ovo živo pravno područje pa je stoga i česta izmjena propisa koji ga uređuju. Međutim novi propisi često stvaraju nepredvidive odnose i situacije, tako da su se s obzirom na zadiranje u vlasnička prava u području prostornog uređenja pojavila neka nova pitanja na koja u praksi do tada nije bilo odgovora, odnosno nije bilo odgovora koji bi bili u skladu sa suvremenim poimanjem prava vlasništva i prava na mirno uživanje vlasništva.

Prema ZPU-u, a isto je propisivao i raniji propis, vlasnik i nositelj drugih stvarnih prava na nekretnini za koju se izdaje lokacijska dozvola uvijek je stranka u postupku izdavanja lokacijske dozvole. ${ }^{5}$ Jednako je propisano i za postupak izdavanja dozvole za promjenu namjene i uporabu građevine ${ }^{6}$, a primjenom općih pravila o svojstvu stranke u upravnom postupku, ${ }^{7}$ strankom treba priznati i vlasnika nekretnine u postupcima utvrđenja građevne čestice. Međutim, u praksi se pojavilo pitanje u kojoj se mjeri i kojem opsegu u postupcima provedbe prostornih planova štite prava i interesi vlasnika nekretnine. To pitanje posebno dolazi do izražaja u postupcima izdavanja lokacijskih dozvola za izgradnju infrastrukturnih objekata, jer je u njima, iz razloga koji će biti objašnjen infra, mogućnost odabira više rješenja u okviru važeće prostornoplanske dokumentacije veća nego u drugim slučajevima. Prema iskustvu autora, upravna tijela su u postupcima izdavanja lokacijskih dozvola za izgradnju infrastrukturnih objekata u praksi svoja postupanja svodila na ispitivanje usklađenosti zahvata s prostornoplanskom dokumentacijom, a zahtjeve i prigovore vlasnika zemljišta da se u okviru prostornoplanske dokumentacije teret $\mathrm{i}$ zadiranje u pravo vlasništva ravnomjernije raspodijeli s drugim subjektima, bez obzira na to koliko su ti prigovori konkretni i argumentirani bili, odbijala uz obrazloženje da se u postupku izdavanja lokacijske dozvole ne rješavaju imovinskopravni odnosi već utvrđuju lokacijski uvjeti zahvata u prostoru i da će vlasnici prigovore imovinskopravne naravi moći iznositi u postupku izvlaštenja.

Predmet je ovoga rada pokušati dati odgovor na pitanje ima li u postupcima provedbe prostornih planova mjesta zaštiti prava i interesa vlasnika zemljišta ${ }^{8}$ ili se u tim postupcima mora prihvatiti svaki zahtjev podnositelja koji je u skladu s prostornoplanskom dokumentacijom. Glavnina rada odnosi se na postupke izdavanja lokacijskih dozvola radi izgradnje infrastrukturnih objekata gdje se, ako bi odgovor na osnovno pitanje bio da se u postupcima provedbe prostornih planova utvrđuje isključivo usklađenost s prostornoplanskom dokumentacijom i da mjesta drugoj zaštiti vlasničkih prava nema, nameće i pitanje ima li onda u tim postupcima smisla i potrebe da se vlasnika zemljišta određuje strankom. Dio rada koji se odnosi na postupke

nekretnine. Više o promjenama stvarnog prava: Gavella, N. i dr., op. cit., str. 218.-233.

5 Čl. 141. ZPU-a, čl. 110. ranije važećeg Zakona o prostornom uređenju i gradnji, NN, br. 76/07., dalje: ZPUiG.

6 Čl. 154. ZPU-a.

7 Čl. 4. Zakona o općem upravnom postupku, NN br. 47/09., dalje: ZUP.

8 U radu koristimo pojam zaštita prava vlasništva pri ćemo mislimo na zaštitu prava i interesa vlasnika zemljišta. Pojam se, dakle, koristi u širem smislu od pojma koji u stvarnom pravu podrazumijeva tužbe radi zaštite prava vlasništva. 
promjene namjene građevine i utvrđenja građevne čestice pretežno je ograničen na pitanje ovisi li ishod tih postupaka o volji vlasnika zemljišta.

Odgovore na ova pitanja pokušat ćemo dati analizom mjerodavnih propisa, ponajprije ZPU-a, Zakona o vlasništvu i drugim stvarnim pravima, ${ }^{9}$ Ustava Republike Hrvatske $^{10}$ i Europske konvencije za zaštitu ljudskih prava i temeljnih sloboda ${ }^{11}$ te mjerodavne upravnosudske prakse, prakse Ustavnog suda Republike Hrvatske i Europskog suda za ljudska prava.

\section{PROSTORNI PLANOVI}

Prostornim planovima propisuju se uvjeti za građenje građevina i provedbu drugih zahvata u prostoru. Ranije je rečeno da su to opći normativni akti koje donose predstavnička tijela, pri čemu je ZPU precizirao da prostorni planovi imaju snagu i pravnu prirodu podzakonskih propisa. Obvezno sadrže tekstualni i grafički dio, što je karakteristika koja ih čini specifičnima u odnosu na druge propise. Donose se na državnoj, područnoj (regionalnoj) i lokalnoj razini. Prostorni plan mora biti u skladu sa ZPU-om i propisima donesenim na temelju toga Zakona. Prostorni plan niže razine mora biti usklađen s prostornim planom više razine, a prostorni plan užeg područja s prostornim planom šireg područja iste razine. Prostorni planovi iste razine moraju biti međusobno usklađeni. Prostornim planom lokalne razine užega područja mogu se propisati stroži kvantitativni i kvalitativni uvjeti i mjere za provedbu zahvata $\mathrm{u}$ prostoru, odnosno viši prostorni standardi od onih propisanih prostornim planom lokalne razine širega područja. ${ }^{12}$

Neovisno o razini koju uređuju, prostorni planovi mogu se podijeliti na: 1 . državni plan prostornog razvoja, 2. prostorne planove područja posebnih obilježja, 3 . prostorne planove (uređenja) županije, grada Zagreba, grada ili općine, 4. urbanističke planove uređenja (državnog značaja, županijskog značaja, lokalne razine) i 5. generalne urbanističke planove. ${ }^{13}$ Ranije važeći Zakon o prostornom uređenju i gradnji i Zakon o prostornom uređenju iz $1994 .{ }^{14}$ poznavali su još i detaljni plan uređenja, koji je u odnosu na navedene planove bio plan najniže razine i najdetaljnije razrade.

Sadržaj prostornih planova propisan je ZPU-om i Pravilnikom o sadržaju, mjerilima kartografskih prikaza, obveznim prostornim pokazateljima i standardu elaborata prostornih planova. ${ }^{15}$

9 Zakon o vlasništvu i drugim stvarnim pravima, br. NN, 91/96., 68/98., 137/99., 22/00., 73/00., 114/01., 79/06., 141/06., 146/08., 38/09., 153/09., 90/10., 143/12., 152/14., dalje: ZV.

10 Ustav Republike Hrvatske, NN br. 56/90., 135/97., 113/00., 28/01., 76/10., 5/14., dalje: Ustav.

11 Konvencija za zaštitu ljudskih prava i temeljnih sloboda, NN MU, br. 18/97, 14/02, 13/03, 9/05, 1/06, 2/10, 13/17, dalje: Konvencija.

12 Čl. 53.-81. ZPU-a.

13 Ibid.

14 Zakon o prostornom uređenju, NN br. 30/94, dalje: ZPU/1994.

15 Pravilnik o sadržaju, mjerilima kartografskih prikaza, obveznim prostornim pokazateljima i standardu elaborata prostornih planova, NN br. 106/98., 39/04., 45/04., 163/04., 153/13., dalje: Pravilnik o sadržaju, mjerilima kartografskih prikaza, obveznim prostornim pokazateljima i standardu elaborata prostornih planova. 
ZPU koristi pojam prostorni planovi kao opći pojam za opće normativne akte u prostornom uređenju, dok teorija prostornog planiranja ${ }^{16}$ rabi pojam planovi prostornog uređenja i dijeli ih na prostorne planove i urbanističke planove, pa tako urbanistički plan definira kao plan koji se bavi unutarnjim prostornim uređenjem naselja i gradova, a prostorni plan kao plan kojega je predmet uređenje ukupnog prostora.

Stariji propisi, ${ }^{17}$ a ta se podjela susreće i danas, ${ }^{18}$ dijelili su prostorne planove na strateške (razvojne) i provedbene, prema tome određuju li temeljnu razdiobu prostora i smjernice za izradu prostornih planova uže razine ili uvjete za neposrednu provedbu zahvata u prostoru unutar dijela svoga obuhvata. ZPU-om, kao ni Pravilnikom o sadržaju, mjerilima kartografskih prikaza, obveznim prostornim pokazateljima i standardu elaborata prostornih planova, nije propisano koji bi to bili provedbeni prostorni planovi, odnosno planovi na temelju kojih je gradnja dopuštena neposrednom primjenom, već je u pravilu samim prostornim planovima propisano što se i pod kojim uvjetima može graditi neposrednom primjenom plana. Međutim, iz odredbi ZPU-a koje uređuju sadržaj prostornih planova i razloge obveznog donošenja prostornog plana niže razine, može se zaključiti da je gradnja neposrednom primjenom moguća na temelju prostornog plana uređenja grada ili općine, generalnog urbanističkog plana i urbanističkog plana uređenja. ${ }^{19}$

Od prostornih planova kojima je gradnja moguća neposrednom primjenom samo je za urbanistički plan uređenja propisano da sadrži prikaz građevnih čestica, a iznimno i generalni urbanistički plan može propisivati uvjete zahvata detaljnošću propisanom za urbanistički plan uređenja. ${ }^{20}$ Pravilnikom o sadržaju, mjerilima kartografskih prikaza, obveznim prostornim pokazateljima i standardu elaborata prostornih planova, propisano je da se kartografski prikazi prostornih planova izrađuju za prostorni plan uređenja općine ili grada na topografskoj karti u mjerilu 1:25.000 i katastarskom planu u mjerilu 1:5.000 za građevinska područja naselja, za generalni urbanistički plan na osnovnoj državnoj karti u mjerilu 1:5.000 i/ili 1:10.000 te za urbanistički plan uređenja na osnovnoj državnoj karti u mjerilu 1:5.000 ili topografsko-katastarskom planu u mjerilu 1:1.000 ili 1:2.000. ${ }^{21}$

Kod prostornih planova na temelju kojih je gradnja moguća neposrednom primjenom, detaljnost razrade, vrsta kartografske podloge i mjerilo kartografskog prikaza određena je u širokom rasponu, samo u odnosu na kartografsko mjerilo od 1:1.000 do 1:10.000, a što je detaljnost razrade i mjerilo kartografskog prikaza

16 Marinović - Uzelac, A., Prostorno planiranje, Zagreb, Dom i svijet, 2001., str. 11. i 16.

17 Npr. Zakon o prostornom uređenju i korištenju građevinskog zemljišta, NN, br. 14/73. ili Zakon o prostornom planiranju i uređenju prostora, $\mathrm{NN}$ br. $54 / 80$.

18 Npr. Mrak - Taritaš, A., Analiza stanja u prostoru i normativnom uređenju kao podloga za izradu novog zakona o prostornom uređenju i gradnji, Osamnaesti forum poslovanja nekretninama, Zagreb, Hrvatska gospodarska komora, 2012., str. 31.

19 Može se reći da su od prostornih planova propisanih ZPU-om državni plan prostornog razvoja, prostorni planovi područja posebnih obilježja, prostorni planovi županija i prostorni plan uređenja grada Zagreba strateški, odnosno razvojni prostorni planovi, urbanistički plan uređenja je provedbeni prostorni plan, a prostorni plan uređenja grada ili općine grada i generalni urbanistički plan ujedno su razvojni i provedbeni planovi.

20 Čl. 78. i 80. ZPU-a.

21 Čl. 17. Pravilnika. 
manja, lakše je udovoljiti uvjetima prostornoplanske dokumentacije a sloboda je pri određivanju lokacijskih uvjeta zahvata veća.

\section{AKTI ZA PROVEDBU PROSTORNIH PLANOVA}

Prostorni planovi provode se izdavanjem: 1. lokacijske dozvole, 2. građevinske dozvole, kada se građevinska dozvola izdaje kao objedinjeni akt kojim se odobrava građenje i akt provedbe prostornih planova, 3. dozvole za promjenu namjene i uporabu građevine, 4. rješenja o utvrđivanju građevne čestice i 5. potvrde parcelacijskog elaborata. ${ }^{22}$

Lokacijskom dozvolom, najjednostavnije rečeno, utvrđuje se je li planirani zahvat $\mathrm{u}$ skladu $\mathrm{s}$ prostornoplanskom dokumentacijom te drugim mjerodavnim propisima i pod kojim uvjetima se može izvesti. Od kada je uvedena ZPU-om/1994 lokacijska dozvola zadržala se kroz sve izmjene propisa i potvrdila kao najdugovječniji, najprepoznatljiviji, a i najzastupljeniji akt provedbe prostornih planova. U početku se lokacijska dozvola izdavala za svaki zahvat u prostoru ${ }^{23}$ i uslijedilo bi joj izdavanje građevinske dozvole kao akta kojim se odobrava građenje, da bi ZPUiG-om, radi ubrzanja i racionalizacije postupka, ${ }^{24}$ za manje zahtjevne građevine bilo uvedeno rješenje o uvjetima građenja ${ }^{25}$, koje je objedinjavalo akt provedbe prostornih planova i akt kojim se odobrava građenje. Pozitivno iskustvo rješenja o uvjetima građenja zadržano je i prošireno zakonodavnom reformom prostornog uređenja i građenja iz kraja 2013., tako da je prema sada važećim ZPU-u i Zakonu o gradnjii26 građevinska dozvola osim akta kojim se odobrava građenje, u pravilu i akt provedbe prostornih planova, što znači da joj ne prethodi izdavanje lokacijske dozvole, a lokacijska dozvola se izdaje samo u taksativno navedenim slučajevima, u kojima će od nekih uslijediti i građevinska dozvola, a kod zahvata koji se ne smatraju građenjem, ne. Od zahvata koji se smatraju građenjem, što je jedino bitno za predmet ovoga rada, lokacijska dozvola se izdaje za: 1. građenje na zemljištu, odnosno građevini za koje investitor nije riješio imovinskopravne odnose ili za koje je potrebno provesti postupak izvlaštenja, 2. etapno i fazno građenje građevina, 3 . određivanje novih vojnih lokacija i vojnih građevina i 4 . kad stranka to sama zatraži. ${ }^{27}$ Međutim, bez obzira na to provodi li se postupak izdavanja lokacijske dozvole, lokacijski uvjeti se u građenju osim u iznimnim slučajevima uvijek utvrđuju, ${ }^{28} \mathrm{i}$ u biti nema razlike utvrđuju li se u postupku građevinske ili lokacijske dozvole, pa sve što je ili će biti u ovom radu rečeno za lokacijsku dozvolu mutatis mutandis vrijedi i za građevinsku dozvolu.

22 Čl. 114. st. 2. ZPU-a.

23 Čl. 34. ZPU/1994.

24 Mrak - Taritaš, A., Lokacijska dozvola od prostornog plana do upravnog akta, Četrnaesti forum poslovanja nekretninama, Zagreb, Hrvatska gospodarska komora, 2009., str. 61.

25 Čl. 213. Zakona o prostornom uređenju i građenju.

26 Zakon o gradnji, NN, br. 153/13, 20/17, dalje: ZG.

27 Čl. 125.-150. ZPU-a, čl. 106.-127. ZG-a.

28 Lokacijski uvjeti neće se utvrđivati kada se gradnji može pristupiti bez građevinske dozvole, sukladno odredbama čl. 128.-130. Zakona o gradnji i Pravilnika o jednostavnim i drugim građevinama i radovima, NN, br. 112/17. 
Lokacijski uvjeti koji se određuju lokacijskom dozvolom jesu lokacija i smještaj zahvata u prostoru, vrsta radova (gradnja ili rekonstrukcija građevine i sl.), namjena građevine, veličina građevine, veličina i oblik građevne čestice odnosno obuhvata zahvata u prostoru, uvjeti priključenja građevine na prometnu i infrastrukturu, mjere sprječavanja nepovoljnih uvjeta na okoliš, posebni uvjeti nadležnih javnopravnih tijela (vodopravni uvjeti, konzervatorski uvjeti i sl.) i drugo. Sastavni dio lokacijske dozvole je idejni projekt kojim se, između ostalog, određuje smještaj građevine na građevnoj čestici, odnosno obuhvata zahvata u prostoru. ${ }^{29}$

Dozvolom za promjenu namjene i uporabu građevine se na zahtjev vlasnika nekretnine ili njezinog posebnog dijela mijenja namjena postojeće građevine ili drugi lokacijski uvjet, kada za promjenu namjene nije potrebno izvođenje građevinskih radova za koje je potrebna građevinska dozvola. Na temelju dozvole za promjenu namjene i uporabu građevine, građevina se može koristiti za novu namjenu i može se izdati rješenje za obavljanje djelatnosti u skladu s novom namjenom. ${ }^{30}$

Rješenje o utvrđivanju građevne čestice donosi se: 1. ako za postojeću građevinu nije utvrđena građevna čestica, odnosno zemljište nužno za redovitu uporabu građevine, 2. kada je obveza utvrđivanja građevne čestice odnosno zemljišta nužnog za redovitu uporabu građevine propisana posebnim zakonom i 3. kada vlasnik građevine želi promijeniti oblik i veličinu građevne čestice. ${ }^{31}$

Potvrdom parcelacijskog elaborata upravno tijela nadležno za prostorno uređenje potvrđuje da je parcelacijski elaborat izrađen u skladu s prostornoplanskom dokumentacijom i aktima prostornog uređenja, odnosno lokacijskom ili građevinskom dozvolom, rješenjem za promjenu namjene i uporabu građevine te rješenjem o utvrđenju građevne čestice. ${ }^{32} \mathrm{Za}$ razliku od ostalih akata za provedbu prostornih planova, potvrda parcelacijskog elaborata ne izdaje se u obliku upravnog akta, već u formi potvrde, otiskivanjem štambilja na naslovnu stranicu elaborata ili kao zasebna potvrda koja se prilaže elaboratu..$^{33}$ Tek ako nisu ispunjene pretpostavke za izdavanje potvrde donosi se rješenje $u$ formi upravnog akta kojim se zahtjev odbija. Potvrda parcelacijskog elaborata svodi se isključivo na utvrđenje je li parcelacijski elaborat izrađen u skladu s prostornoplanskom dokumentacijom i aktima prostornog uređenja, pri čemu se ne ulazi u imovinskopravne odnose subjekata pa nema ni potrebe da se obradi u ovome radu.

\section{ZAS̆TITA PRAVA VLASNIŠTVA U POSTUPCIMA IZDAVANJA LOKACIJSKIH I GRAĐEVINSKIH DOZVOLA}

Od kada je ZPUiG prvi puta propisao tko može biti stranka u postupku izdavanja lokacijske dozvole, strankom se priznaje podnositelj zahtjeva, vlasnik i nositelj drugih

29 Čl. 128. i 140. ZPU-a.

30 Čl. 151. i 152. ZPU-a.

31 Čl. 157. ZPU-a.

32 Čl. 160. i 162. ZPU-a, čl. 9. Pravilnika o parcelacijskim i drugim geodetskim elaboratima, NN, br. 86/07, 25/09, 148/09., dalje: Pravilnik o parcelacijskim i drugim geodetskim elaboratima.

33 Čl. 84. Pravilnika o parcelacijskim i drugim geodetskim elaboratima. 
stvarnih prava na nekretnini za koju se izdaje lokacijska dozvola, te vlasnik i nositelj drugih stvarnih prava na nekretnini koja s nekretninom za koju se izdaje lokacijska dozvola neposredno graniči. Iznimno od navedenog, u postupcima za provedbu zahvata od interesa za Republiku Hrvatsku ili kada lokacijsku dozvolu koju izdaje Ministarstvo, od nositelja stvarnih prava stranka je samo vlasnik i nositelj drugih stvarnih prava na nekretnini za koju se izdaje lokacijska dozvola. ${ }^{34}$

Međutim, nikada nije bilo propisano radi zaštite kojih prava $i$ interesa su navedeni stvarnopravni ovlaštenici u postupku izdavanja lokacijske dozvole određeni strankom, odnosno koja prava i interese mogu s uspjehom štititi i koje prigovore iznositi.

Iako nikada nije bilo propisano ovisi li izdavanje lokacijske dozvole o pristanku ostalih stranaka različitih od podnositelja zahtjeva, odnosno vlasnika i nositelja drugog stvarnog prava na zahvaćenoj ili susjednoj nekretnini, vrlo je rano upravnosudska praksa zauzela stav da izdavanje lokacijske dozvole ne ovisi o pristanku ostalih stranaka, uz obrazloženje da se lokacijskom dozvolom ne stječe pravo na građenje niti ne razrješuju imovinsko pravni odnosi..$^{35}$ Međutim, ne bi imalo smisla da lokacijsku dozvolu može ishodovati svatko, pa i nevlasnik za kojeg je izvjesno da nikada neće moći dobiti građevinsku dozvolu jer mu nedostaje suglasnost vlasnika, ${ }^{36}$ stoga je razvijena i upravnosudska praksa o pravnom interesu za izdavanje lokacijske dozvole, ${ }^{37}$ koja je ZPUiG-om uobličena u zakonsku normu kao pretpostavka za izdavanje lokacijske dozvole $^{38}$ a ona u bitnom znači da pravni interes za izdavanje lokacijske dozvole ima osoba za koju je realno očekivati da će moći ishodovati građevinsku dozvolu, u prvom redu vlasnik ili nositelj prava građenja, odnosno stranka koja posjeduje drugu ispravu temeljem koje može dobiti građevinsku dozvolu, kao i svaki investitor koji učini vjerojatnim da će na temelju relevantnih propisa, izvlaštenjem ili drugim načinom steći pravo na građenje. Novim ZPU-om pravni interes za izdavanje lokacijske dozvole u biti je izjednačen s pravnim interesom za izdavanjem građevinske dozvole propisanim ZG-om i uobličen je u upravo one pretpostavke do kojih je došla i dotadašnja upravnosudska praksa, dakle pravo vlasništva ili pravo građenja, suglasnost njihovih nositelja te odredba zakona o interesu Republike Hrvatske ili tko može provoditi određeni zahvat.

Međutim, nisu svi prigovori stranaka u postupku izdavanja lokacijske odnosno građevinske dozvole ograničeni na protivljenje zahvatu. Stranke su često svjesne da svojim protivljenjem ne mogu osujetiti planirani zahvat pa pokušavaju da se zahvat izvede tako da što manje šteti njihovim pravima i interesima. Ovdje ćemo kod analize u kojoj se mjeri u postupcima izdavanja lokacijskih, odnosno građevinskih

34 Čl. 141. ZPU-a, čl. 110. ZPUiG-a.

35 Upravni sud Republike Hrvatske, Us-3696/1996 od 5. veljače 1996., Visoki upravni sud Republike Hrvatske, Zbornik odluka 1977.-2017., Zagreb, Narodne novine, 2017., str. 239.

36 Kao pretpostavka za izdavanje građevinske dozvole uvijek je bio propisan dokaz prava vlasništva ili taksativno navedenog drugog ovlaštenja; čl. 50. Zakona o gradnji, NN, br. 52/99, čl. 214. ZPUiG-a, čl. 109. ZG-a.

37 Upravni sud Republike Hrvatske, Us-575/1996 od 18. srpnja 1996., Visoki upravni sud Republike Hrvatske, op. cit., str. 237.

38 Čl. 107. ZPUiG-a. 
dozvola u dijelu u kojem je to akt provedbe prostornih planova, štite prava i interesi vlasnika zemljišta podijeliti izlaganje na slučajeve kada se zahtjev za izdavanje akta provedbe plana odnosi na nekretninu koje je stranka vlasnik i kada se zahtjev odnosi na nekretninu s kojom nekretnina u vlasništvu stranke neposredno graniči.

\subsection{Zaštita prava na nekretninama iz zahvata za koji se provodi postupak izdavanja lokacijske dozvole}

S obzirom na ranije rečeno o pravnom interesu za izdavanje lokacijske dozvole, vlasnik nekretnine iz zahvata za izdavanje lokacijske dozvole s različitim i pretpostavljeno suprotstavljenim interesima u odnosu na podnositelja zahtjeva, javit će se samo kod izdavanja lokacijske dozvole za izvođenje zahvata od interesa za Republiku Hrvatsku kojima će uslijediti postupak izvlaštenja. Kod provedbe zahvata koji nisu od interesa za Republiku Hrvatsku realizacija će sve do mogućnosti zabrane ovisiti isključivo o volji vlasnika, stoga nam oni nisu bitni za predmet ovoga rada. Isto tako, kao što je navedeno ranije, kada se mora provesti izvlaštenje uvijek provode odvojeni postupci izdavanja lokacijske i građevinske dozvole, stoga do pravnih pitanja o kojima će biti riječi u ovome dijelu, može doći samo u postupku izdavanja lokacijske dozvole.

U svezi sa zadiranjem u vlasnička prava i poziciju vlasnika zemljišta posebno su predmeti izdavanja lokacijskih dozvola za gradnju prometnica, komunalnih građevina, plinovoda i sličnih infrastrukturnih objekata, postavila pred nadležna tijela pitanja na koja u praksi do tada nije bilo odgovora, odnosno nije bilo odgovora koji bi bili u skladu sa suvremenim poimanjem prava vlasništva i prava na mirno uživanje vlasništva. Vlasnici zemljišta u tim su postupcima često pred upravnim tijelima iznosili konkretne i argumentirane prigovore usmjerene tomu da se položaj zahvata utvrđenog idejnim rješenjem izmjesti tako da se u okviru prostornoplanske dokumentacije teret $\mathrm{i}$ zadiranje u pravo vlasništva ravnomjernije raspodijeli s drugim subjektima.

Možda će to pitanje najslikovitije dočarati predmet Upravnog suda u Rijeci UsI-1400/12 u kojem je predmet spora bila lokacijska dozvola radi izgradnje državne ceste D-403 od čvora Škurinje do luke Rijeka, čija je trasa ucrtana u kartografskom dijelu Generalnog urbanističkog plana grada Rijeke ${ }^{39}$, izrađenog u mjerilu 1:10.000. Osim navedene državne ceste kako je predviđena prostornim planom, osporenom lokacijskom dozvolom bila je određena izgradnja spojne ceste koja nije bila ucrtana u kartografskom dijelu generalnog urbanističkog plana, ali su njene dimenzije i ostali uvjeti gradnje bili u skladu s odredbama za provođenje. Tužbu je podnijelo trgovačko društvu u čijem se vlasništvu nalazi mljekara zahvaćena spojnom cestom. Lokacijskom dozvolom bilo je predviđeno rušenje dijela postrojenja mljekare na mjestu gdje se nalaze separatori i parkirališta, što bi po navodima tužitelja značilo prestanak rada mljekare, jer na predmetnoj lokaciji nema mjesta na koji bi se izmjestio dio postrojenja koji se ruši. Uz to je tužitelj tvrdio da je u mljekari zaposleno preko

39 Generalni urbanistički plan grada Rijeke, SN Primorsko-goranske županije br. 7/07., 14/13., 8/14., od vremena kada se navedeni spor vodio do dana pisanja ovoga rada stupile su na snagu i izmjene i dopune br. 3/17., dalje GUP grada Rijeke. 
100 radnika te da ona posluje s više od 500 obiteljskih gospodarstava, čime je za poslovanje mljekare neizravno vezano oko 2500 ljudi.

Kao što je ranije navedeno, neposrednom primjenom plana moguća je gradnja, odnosno izdavanje lokacijske dozvole na temelju prostornog plana uređenja grada ili općine, generalnog urbanističkog plana i urbanističkog plana uređenja, tako što je u pravilu samim prostornim planovima propisano što se i pod kojim uvjetima može graditi neposrednom primjenom plana, pri čemu je urbanistički plan uređenja čisto provedbeni plan, dok su prostorni plan uređenja grada ili općine grada i generalni urbanistički plan ujedno razvojni i provedbeni planovi.

Koliki je raspon detaljnosti razrade i preciznosti prikaza infrastrukturnih građevina na navedenim planovima neposredne primjene, dat ćemo sukladno navedenom primjeru iz upravnosudske prakse, na primjeru prometne infrastrukture. Rekli smo već da se kartografski prikaz za prostorni plan uređenja općine ili grada izrađuje na topografskoj karti u mjerilu 1:25.000 i katastarskom planu u mjerilu 1:5.000 za građevinska područja naselja, za generalni urbanistički plan na osnovnoj državnoj karti u mjerilu 1:5.000 i/ili 1:10.000 te za urbanistički plan uređenja na osnovnoj državnoj karti u mjerilu 1:5.000 ili topografsko-katastarskom planu u mjerilu 1:1.000 ili 1:2.000. Prostorni planovi višeg reda, između ostalog prostorni plan uređenja grada ili općine i generalni urbanistički plan uređenja određuju funkciju prometnice sagledavajući cjelovitu osnovnu prometnu mrežu uz istodobno grubo određenje u prostoru. Studijska rješenja usmjerena su na određivanje funkcije i ranga prometnice, osnovnog smjera pružanja i broja čvorišnih točaka, a manje na prostorno detaljnije određenje ili određenje drugih pratećih elemenata. Urbanističkim planom uređenja prometnice se detaljnije određuju pa je raspon slobode kod projektiranja konačnog rješenja ovdje već prilično zatvoren..$^{40}$

Kod nas ni jednim propisom nije zadana jedinstvena podjela prometnica u prostornom uređenju, a najčešće se one dijele na glavne mjesne ulice ili ceste, sabirne ulice ili ceste i ostale ulice ili ceste. ${ }^{41}$ Prostornim planovima grada ili općine, generalnim urbanističkim planovima i urbanističkim planovima uređenja u pravilu je propisano da je neposrednom provedbom plana dopuštena gradnja novih te rekonstrukcija postojećih glavnih mjesnih, sabirnih i ostalih ulica. ${ }^{42} \mathrm{U}$ tekstualnim odredbama za provođenje planova dane su dimenzije i ostali uvjeti gradnje odnosno rekonstrukcije za pojedine vrste ceste, dok su u kartografskom prikazima za prostorni plan uređenja grada ili općine i generalni urbanistički plan prikazane glavne mjesne

40 Krpan, Lj., Značenje prometne infrastrukture u prostornom planiranju, Prostorno planiranje u Primorsko - goranskoj županiji: povijest-stanje-perspektive, Rijeka, Zavod za prostorno planiranje Primorsko - goranske županije, 2011., str.160. i 161.

41 Više o podjeli prometnica u prostornom uređenju: Poropat, A., Identifikacija parcele prometnice u naselju, Zagreb, Glasilo Hrvatske komore arhitekata i inženjera u graditeljstvu, br. 18, 2005.

42 Npr. čl. 107.a. Prostornog plana uređenja Grada Pule, SN Grada Pule, br. 12/06, 12/12, 5/14, 7/15, 10/15- pročišćeni tekst, 5/16, 2/17, 5/17, dalje: PPU Grada Pule; čl. 135. GUP-a grada Rijeke; čl. 116. Generalnog urbanističkog plana uređenja Grada Pule, SN Grada Pule br. 5a/08, 12/12, 5/14, 10/14, 13/14, 7/15, 2/17 i 5/17, dalje: GUP Grada Pule; čl. 48. Urbanističkog plana uređenja gradskog područja Gornja Drenova, SN Primorsko-goranske županije, br. 21/10, dalje: UPU Gornja Drenova. 
i sabirne ulice, a kod urbanističkog plana uređenja sve vrste. ${ }^{43}$ Pri rekonstrukciji postojećih prometnica trasa nove prometnice, osim eventualno kod urbanističkog plana uređenja, u pravilu nije ucrtana u kartografskom prikazu, već su uvjeti gradnje zadani samo odredbama za provođenje, tako da ostaje otvoreno pitanje s koje strane će se prometnica proširivati. ${ }^{44}$ Urbanističkim planom uređenja može biti predviđena i gradnja ostalih ulica koje nisu prikazane u kartografskom prikazu..$^{45}$

Iz navedenog vidimo da sloboda i raspon unutar kojeg je u postupku izdavanja lokacijske dozvole moguće prikazati građevnu česticu prometnice i smještaj građevine, koja će biti u skladu s prostornim planom, ovisi o nekoliko čimbenika: razini i detaljnosti prostornog plana, je li prometnica prikazana u kartografskom prikazu plana te radi li se o gradnji nove ili rekonstrukciji postojeće prometnice.

Sloboda određivanja građevne čestice i smještaja građevine otvara i mogućnost zadovoljenja više interesa te nas dovodi do središnjeg pitanja u ovome radu: ima li u postupcima izdavanja lokacijskih dozvola radi izdavanja infrastrukturnih objekata, mjesta zaštiti prava i interesa vlasnika i nositelja drugih stvarnih prava na nekretninama ili se u tim postupcima mora prihvatiti svaki zahtjev podnositelja koji je u skladu s prostornoplanskom dokumentacijom, bez obzira na to koliko on tegoban za nekog vlasnika bio?

Već smo rekli da su vlasnici zemljišta u postupcima izdavanja lokacijskih dozvola za izgradnju infrastrukturnih objekata često pred upravnim tijelima prostornog uređenja iznosili konkretne i argumentirane prigovore usmjerene tomu da se položaj zahvata predloženog idejnim rješenjem izmjesti tako da se u okviru prostornoplanske dokumentacije teret $\mathrm{i}$ zadiranje u pravo vlasništva ravnomjernije raspodijeli s drugim subjektima. Takve prigovore upravna tijela u pravilu su odbijala, uz obrazloženje da se u postupku izdavanja lokacijske dozvole ne rješavaju imovinskopravni odnosi već utvrđuju lokacijski uvjeti zahvata te da je u provedenom postupku utvrđeno kako je zahvat u skladu s prostornoplanskom dokumentacijom, a da će vlasnici prigovore imovinskopravne naravi moći iznositi u postupku izvlaštenja. Prije nego što uđemo u analizu ovoga pitanja, valja istaknuti da je netočno da se prigovori u svezi s položajem trase infrastrukturne građevine mogu iznositi u postupku izvlaštenja, jer se izvlaštenje provodi za točno određenu trasu utvrđenu lokacijskom dozvolom i geodetskim elaboratom izvlaštenja, koji se uz ostalu dokumentaciju prilažu uz prijedlog za izvlaštenje, pa se u postupku izvlaštenja može raspravljati samo o visini naknade za izvlaštenje i eventualno o izvlaštenju preostalog dijela nekretnine ${ }^{46}$, a utvrđena trasa se više ne može mijenjati. Stoga, kada bi se vlasnicima zemljišta onemogućilo da o smještaju infrastrukturnih građevina raspravljaju i u postupku lokacijske dozvole, uskratila bi im se protiv takvog zadiranja u pravo vlasništva bilo kakva pravna zaštita.

ZPU je propisao da se lokacijska dozvola izdaje nakon što je u provedenom postupku utvrđeno da je uz zahtjev priložena sva propisana dokumentacija i ako su utvrđeni svi posebni uvjeti, a izmjenama i dopunama Zakona iz 2017. dodano je i

43 Npr. PPU Grada Pule, GUP grada Rijeke, GUP Grada Pule, UPU Gornja Drenova.

44 Ibid.

45 Npr. UPU Gornja Drenova.

46 Čl. 30., 46.-57. Zakona o izvlaštenju i određivanju naknade, NN br. 74/14, 69/17, čl. 20., 32-35 ranijeg Zakona o izvlaštenju, NN. br. 9/94., 35/94., 112/00., 114/01., 79/06., 45/11., 34/12. 
ako je idejni projekt izrađen u skladu s prostornim planom. ${ }^{47}$ Iz navedene odredbe dalo bi se zaključiti da je izmjenama i dopunama Zakona otklonjena dvojba uzimaju li se u postupcima izdavanja lokacijskih dozvola u obzir prava i interesi stranaka, tako što se u tim postupcima utvrđuje isključivo usklađenost s prostornoplanskom dokumentacijom i lokacijska dozvola izdaje za svaki zahvat koji je u skladu s prostornim planom.

Međutim, navedena odredba nije jedini, a ni najviši izvor prava koji se ima primijeniti u postupcima izdavanja lokacijske dozvole.

Već je među samim načelima prostornog uređenja propisano da se prostorno uređenje temelji, između ostalog, na načelu ostvarivanja i zaštite javnog i pojedinačnog interesa te da se javni interes štiti razgraničenjem prostora za javne namjene od ostalog prostora vodeći pri tom računa da svi korisnici, koliko je to moguće, podjednako snose teret razgraničenja. ${ }^{48}$

Načelo ostvarivanja i zaštite javnog i pojedinačnog interesa uvodi nas do sljedećeg izvora prava u ovom radu: Europske konvencije za zaštitu ljudskih prava i temeljnih sloboda i njenog Prvog protokola kojim je uređeno pravo na mirno uživanje vlasništva. Podsjećamo da je Ustavom propisano da međunarodni ugovori koji su sklopljeni i potvrđeni u skladu s Ustavom čine dio unutarnjega pravnog poretka Republike Hrvatske, a po pravnoj su snazi iznad zakona. Njihove se odredbe mogu mijenjati ili ukidati samo uz uvjete i na način koji su u njima utvrđeni, ili suglasno općim pravilima međunarodnog prava. ${ }^{49}$

Člankom 1. Prvog protokola Konvencije propisano je da svaka fizička ili pravna osoba ima pravo na mirno uživanje svojega vlasništva. Nitko se ne smije lišiti svoga vlasništva, osim u javnom interesu, i to samo uz uvjete predviđene zakonom i općim načelima međunarodnog prava. Stavkom 2. navedenog članka propisano je da prethodne odredbe, međutim, ni na koji način ne umanjuju pravo države da primijeni zakone koje smatra potrebnima da bi uredila upotrebu vlasništva u skladu s općim interesom ili za osiguranje plaćanja poreza ili drugih doprinosa ili kazni.

Europski sud za ljudska prava, odlučujući o povredi prava na mirno uživanje vlasništva, u predmetima Sporrong i Lönroth protiv Švedske (presuda, 23. rujna 1982., br. 7151/75 i 7152/75), Bistrović protiv Hrvatske (presuda, 31. svibnja 2007., br. 25774/05) i drugima, ${ }^{50}$ iznio je stav da svakim miješanjem u mirno uživanje prava vlasništva pojedinca mora biti postignuta poštena ravnoteža između zahtjeva općega interesa zajednice i zahtjeva za zaštitom temeljnih prava pojedinca. Navedeno pravno shvaćanje, kao i s tim s svezi druge naznačene presude Europskog suda za ljudska prava, proizlaze iz postupaka izvlaštenja ${ }^{51}$, stoga se postavlja pitanje mogu li se primijeniti i u postupcima izdavanja lokacijskih dozvola. Pretraživanjem prakse Europskog suda

47 Čl. 146. ZPU-a.

48 Čl. 11. ZPU-a.

49 Čl. 134. Ustava.

50 Ouzounoglou protiv Grčke (presuda, 24. studenog 2005., br. 32730/03), Bivši kralj Grčke i drugi protiv Grčke (presuda, 23. studenog 2000, br. 25701/94), Almeida Garrett, Mascarenhas Falcao i dr. protiv Portugala (presuda, 11. siječnja 2000., br. 29813/96 30229/96) i dr., https:// hudoc.echr.coe.int., 24. veljače 2014.

51 Predmet Sporrong i Lönroth protiv Švedske osim na izvlaštenja odnosio se i na zabranu gradnje. 
za ljudska prava nismo naišli na predmete izdavanja lokacijskih dozvola, međutim pronašli smo više predmeta u kojima je Sud odlučivao o pravu na mirno uživanje vlasništva u postupcima prostornog uređenja. ${ }^{52}$ Doseg i primjenu prava na mirno uživanje vlasništva u području prostornog uređenja prema shvaćanju Europskog suda za ljudska prava po nama najbolje dočarava navod iz obrazloženja presude u predmetu Skibinscy protiv Poljske (presuda, 14. studenog 2006., br. 52589/99): Sud smatra da bi u području gospodarenja zemljištem i prostornog uređenja države ugovornice trebale uživati široku slobodu prosudbe (engl: margin of appreciation) ${ }^{53}$ kako bi provele politiku prostornog planiranja. Ipak, u izvršavanju svoje ovlasti, Sud mora utvrditi je li postignuta ravnoteža koja je u skladu s pravom vlasništva podnositelja zahtjeva. Govoreći o slobodi prosudbe (engl: margin of appreciation) u prostornom uređenju u predmetu Depalle protiv Francuske (presuda, 29. ožujka 2010., br. 34044/02) Sud obrazlaže: Sud je, štoviše, više puta ponovio da u prostornom planiranju i očuvanju okoliša, gdje je opći interes zajednice najvažniji, države ugovornice uživaju slobodu prosudbe (engl: margin of appreciation) koja je veća nego kada su u pitanju isključivo privatna prava.

Smatramo da stoga, sukladno pravnim shvaćanjima Europskog suda za ljudska prava o pravu na mirno uživanje vlasništva, u postupcima izdavanja lokacijskih dozvola radi izgradnje infrastrukturnih objekata ima mjesta zaštiti vlasničkih prava vlasnika nekretnina. Odnosno da se u postupku moraju razmotriti svi prigovori stranaka te da se smještaj i položaj građevine mora odrediti tako da se u okvirima važeće prostornoplanske dokumentacije postigne poštena ravnoteža između zahtjeva općega interesa zajednice i zahtjeva za zaštitom temeljnih prava pojedinca. ${ }^{54}$ To ne znači da se zahtjevima vlasnika zemljišta mora udovoljiti, već da se mora postići ravnoteža kojom će se maksimalno koliko je moguće udovoljiti interesima svih zainteresiranih subjekata, uzimajući u obzir da se prednost uvijek mora treba dati javnom pred pojedinačnim interesom. Osim što smatramo da to proizlazi iz konvencijskog prava, uz to ne vidimo ni jedan logičan i životni razlog koji bi sprječavao da se u postupcima izdavanja lokacijskih dozvola ne bi pokušalo izmiriti opći i privatni interes te naći poštena ravnoteža između njih, poštujući prednost javnog odnosno općeg nad privatnim interesom. Pravo vlasništva je u suvremenim pravnim poredcima obilježeno socijalnom vezanošću, ${ }^{55}$ koja se u prostornom uređenju posebno ističe, što pokazuje i citirana praksa Europskog suda za ljudska prava, koja u prostornom

52 Depalle protiv Francuske (presuda, 29. ožujka 2010., br. 34044/02), Elia S.r.l. protiv Italije (presuda, 2. kolovoza 2001., br. 37710/97), Skibinscy protiv Poljske (presuda, 14. studenog 2006., br. 52589/99) i dr., https://hudoc.echr.coe.int., 29. prosinca 2017.

53 Omejec, J., Ustavno i konvencijsko jamstvo prava vlasništva, Liber amicorum in honorem Jadranko Crnić, Zagreb, Novi informator, 2009., str. 144., objašnjava da područje slobode prosudbe ukazuje na "prostor za manevriranje" koji tijelima Konvencije omogućuje da nacionalnim vlastima država ugovornica ostave određeno područje slobode u postupanju. To nacionalno područje slobode rezervirano za države ugovornice Europski sud neće ispitivati i u njega neće ulaziti.

54 Taj je pravni stav izražen i u presudama Upravnog suda u Rijeci: UsI-1400/12-20 od 13. lipnja 2014, UsI-1563/12-14 od 18. srpnja 2014., UsI-41/13-17 od 13. listopada 2014., UsI-1434/1414 od 28. travnja 2015. i UsI-1046/14-17 od 7. listopada 2016.

55 Gavella, N. i dr., Stvarno pravo, Zagreb, Narodne novine, 2007., Svezak 1., str. 378. 
uređenju državama ugovornicama priznaje širu slobodu prosudbe, nego u čisto privatnopravnim odnosima, tako da vlasnik nekretnine svoje privatnopravne interese ne može s uspjehom suprotstaviti interesima zajednice za gradnjom nekog objekta od općeg interesa. Međutim, to ne znači da se u postupcima provedbe dokumenata prostornog uređenja ne može zadovoljiti i privatni interes ako nije u suprotnosti s javnim. Ovdje ćemo još dodati da je prema općim pravilima stvarnoga prava vlasnik dužan postupati obzirno prema tuđim interesima koji nisu protivni njegovom pravu, ${ }^{56}$ što smatramo da ne isključuje ni postupanja tijela vlasti kada su u pitanju privatni interesi, između ostalog i u postupcima izdavanja lokacijskih dozvola.

Ako sudska praksa zauzme suprotno stajalište, odnosno da se u postupcima provedbe prostornih planova utvrđuje isključivo usklađenost s prostornoplanskom dokumentacijom i da mjesta drugoj zaštiti vlasničkih prava nema, postavlja se i pitanje ima li u tim postupcima smisla i potrebe da se vlasnika nekretnine a i nositelja drugih stvarnih prava određuje strankom.

Europski sud za ljudska prava odlučujući o pravu na pravično suđenje, u predmetima Kreuz protiv Poljske (presuda, 19. lipnja 2001., br. 28249/95) i drugima ${ }^{57}$ istaknuo je da prava zajamčena Konvencijom, a u konkretnom se slučaju mislilo na procesna prava, ne smiju biti teorijska ili prividna, već moraju biti stvarna i djelotvorna. Isto je shvaćanje preuzeo i Ustavni sud Republike Hrvatske u odlukama Broj U-III - 617/2006 od 25. siječnja 2011. i Broj U-III - 3937/2011 od 14. prosinca 2011. govoreći o djelotvornom pravnom sredstvu koje strankama pred domaćim sudovima omogućuje da brane svoja prava.

Smatramo da pravo vlasnika i nositelja drugih stvarnih prava biti strankom u postupku u kojem njihovi navodi nemaju nikakvog utjecaja na zaštitu njihovih prava $\mathrm{i}$ ishod postupka, nije stvarno i djelotvorno, već naprotiv samo prividno i da u tom slučaju uopće nema potrebe da ih se određuje strankom.

\subsection{Zaštita prava na nekretninama koje neposredno graniče s nekretninama iz zahvata za koji se provodi postupak izdavanja lokacijske odnosno građevinske dozvole}

Vlasnik nekretnine koja neposredno graniči s nekretninom iz zahvata za koji se izdaje lokacijska odnosno građevinska dozvola javit će se kao stranka samo u postupcima privatnih investitora, budući da, kao što je ranije rečeno, u postupcima od interesa za Republiku Hrvatske, te posljedično tomu, u postupcima za koje se provodi izvlaštenje, vlasnik susjedne nekretnine nije stranka. Isto tako, u tim predmetima gradnje lokacijski uvjeti utvrđuju se u postupku izdavanja građevinske dozvole. ${ }^{58}$

Vlasnici zgrada na susjednim nekretninama često se protive gradnji želeći zadržati postojeće uvjete života i stanovanja pa se u postupcima izdavanja lokacijskih dozvola pozivaju na svoja stečena prava, ali svjesni slabosti takvih argumenata

56 Čl. 31. ZV-a.

57 Multiplex protiv Hrvatske (presuda, 10. srpnja 2003., br. 58112/00) i dr., https://hudoc.echr.coe. int., 24. veljače 2014.

58 Vidi supra, str. 8. i 9. 
iznose i duge prigovore usmjerene općenito na neusklađenost zahvata sa zakonom i prostornoplanskom dokumentacijom, sve kako bi osujetili provedbu zahvata. Racionalno korištenje i očuvanje kapaciteta prostora, razumno korištenje i zaštita prirodnih dobra, okoliša i prirode te organizirana raspodjela i uređenje građevinskog zemljišta, koji su između ostalog propisani među ciljevima prostornog uređenja ${ }^{59}$, utječu da se socijalna vezanost vlasništva u prostornom uređenju ispoljava snažnije nego u drugim društvenim odnosima. To je potvrdio i Europski sud za ljudska prava priznajući državama ugovornicama u prostornom uređenju po pitanju prava na mirno uživanje vlasništva širu slobodu prosudbe nego u čisto privatnopravnim odnosima. ${ }^{60}$ Smatramo stoga da vlasnici susjednih nekretnina u svezi sa standardom i kvalitetom života i stanovanja kao što su pogled, privatnost, tišina, mir i slično, nemaju i ne mogu steći nikakva prava na temelju kojih bi druge mogli spriječiti da pod istim uvjetima grade u skladu s prostornoplanskom dokumentacijom i mjerodavnim propisima. Visina i katnost građevine, udaljenost građevine od međa, najveća dopuštena izgrađenost građevne čestice i drugi lokacijski uvjeti, uvijek su propisani prostornim planom, a skučenost prostora, odnosno veličina građevne čestice kojom raspolaže investitor u pravilu mu ne ostavljaju veliku slobodu u određivanju dimenzija i smještaja građevine. Smatramo da bi, kada bi se jednom investitoru omogućilo da maksimalno iskoristi zadane parametre lokacijskih uvjeta, te mu se potom dopustilo da pozivom na stečena prava u svezi s kvalitetom i standardom stanovanja onemogući kasnijem investitoru da gradi pod istim uvjetima, povrijedila prava kasnijeg investitora i narušilo načelo socijalne vezanosti vlasništva.

Međutim, prema upravnosudskoj praksi, kod utvrđenja lokacijskih uvjeta treba voditi računa o već utvrđenim uvjetima i legalno izgrađenim građevinama na susjednim česticama. ${ }^{61}$ Ostvarivanje lokacijskih uvjeta za planiranu građevinu u skladu s prostornim planom tako može značiti povredu postojećih zakonito utvrđenih lokacijskih uvjeta na susjednoj građevini. Na primjer, kada se na bočnim pročeljima postojeće zgrade nalaze otvori koji bi se zatvorili ako bi se iskoristila maksimalna dopuštena visina susjedne planirane građevine. U tim slučajevima prostorni planovi znaju sadržavati odredbe kojim se nastoji riješiti kolizija prava pa je tako odredbama PUP-a Stari Grad Pula ${ }^{62}$ propisano da je, u slučajevima Planom omogućene izgradnje na granici sa susjednim postojećim građevinama, a koje na kontaktnom pročelju imaju legalno izvedene otvore, potrebno u postupku izdavanja odobrenja za građenje projektnom dokumentacijom dokazati da nova izgradnja neće omesti osnovnu funkciju postojećih prostorija koje se koriste tim otvorima. Smatramo da se u slučajevima sukoba prava između legalno utvrđenih lokacijskih uvjeta i lokacijskih uvjeta propisanih prostornim planom treba naći ravnoteža između sukobljenih prava i interesa te pokušati im maksimalno koliko je moguće udovoljiti, imajući u vidu koji interes u konkretnom slučaju prevlada. Na primjer, ako se pristupni put koji je sastavni dio zakonito utvrđenih lokacijskih uvjeta nalazi na susjednoj nekretnini,

59 Čl. 6. ZPU-a.

60 Vidi supra, str. 16.

61 Upravni sud Republike Hrvatske, Us-11906/1998 od 2. prosinca 1999. Visoki upravni sud Republike Hrvatske, Zbornik odluka 1977.-2007., Zagreb, Narodne novine, 2007., str. 235.

62 Točka 85. PUP-a "Stari Grad Pula”, SN, br. 6/92, 1/97, 11/07, 2/09. 
vlasnik susjedne nekretnine na tom dijelu neće moći graditi jer bi u tom slučaju drugome u potpunosti onemogućio ostvarenje njegovih prava. Ili s druge strane, ako se na bočnom pročelju legalno izgrađene zgrade nalaze otvori na mjestu gdje je dopuštena gradnja poluugrađene građevine koja se može prisloniti uz zid postojeće građevine, nova će se građevina graditi i otvori u potpunosti ili djelomično zatvoriti a dotok svjetlosti omogućiti svjetlikom ili na drugi primjereni način.

Vlasništvo na susjednoj nekretnini često je povezano s pravom služnosti na nekretnini iz zahvata, kada je susjedna nekretnina u odnosu na nekretninu iz zahvata povlasna nekretnina, pa je nositelj prava vlasništva na susjednoj nekretnini ujedno i nositelj prava služnosti, odnosno drugog stvarnog prava na nekretnini iz zahvata. To nas dovodi do slučaja kada će investitor morati ustuknuti pred pravima vlasnika susjedne nekretnine. Naime, ako je na nekretnini iz zahvata kao poslužnoj osnovana služnost, investitor će sadržaj prava služnosti morati trpjeti te tako planirati i izgraditi svoju građevinu ili eventualno tražiti prelaganje služnosti, odnosno da se izvršenje služnosti preloži na neko drugo za ovlaštenika jednako prikladno mjesto. ${ }^{63}$ Najčešće će tu biti riječ o služnosti puta, odnosno služnosti puta kao nužnog prolaza, a u obzir mogu doći i druge stvarne služenosti, u prvom redu pravo prozora ili pravo imati dio zgrade i naprave na poslužnoj nekretnini. ${ }^{64}$

\section{ZAS̆TITA PRAVA VLASNIŠTVA U POSTUPCIMA IZDAVANJA DOZVOLE ZA PROMJENU NAMJENE I UPORABU GRAĐEVINE}

Dozvolom za promjenu namjene i uporabu građevine se na zahtjev vlasnika nekretnine ili njezina posebnog dijela mijenja namjena postojeće građevine ili drugi lokacijski uvjet, kada za promjenu namjene nije potrebno izvođenje građevinskih radova za koje je potrebna građevinska dozvola. Na temelju dozvole za promjenu namjene i uporabu građevine, građevina se može koristiti za novu namjenu i može se izdati rješenje za obavljanje djelatnosti u skladu s novom namjenom. ${ }^{65}$

Stranke u postupcima izdavanja dozvole za promjenu namjene i uporabu građevine jesu podnositelj zahtjeva, vlasnik nekretnine za koju se izdaje ta dozvola i nositelj drugih stvarnih prava na toj nekretnini. ${ }^{66}$

ZPU-om je propisano da se dozvola za promjenu namjene i uporabu građevine izdaje ako je podnositelj zahtjeva uz zahtjev priložio propisanu dokumentaciju te ako se u postupku utvrdi da je nova namjena u skladu s prostornim planom i posebnim lokacijskim uvjetima. ${ }^{67}$

Međutim, osim navedenih odredbi posebne uvjete za prenamjenu posebnog dijela nekretnine u suvlasništvu (etažno vlasništvo) propisuje i ZV ${ }^{68}$ Prema odredbama ZV-a suvlasnik na čijem je suvlasničkom dijelu uspostavljeno vlasništvo određenoga

63 Čl. 174., 179. ZV-a.

64 Čl. 186.-190. ZV-a.

65 Čl. 151. i 152. ZPU-a.

66 Čl. 154. ZPU-a.

67 Čl. 153. ZPU-a.

68 Čl. 82. ZV-a. 
posebnog dijela nekretnine ovlašten je, ne tražeći za to odobrenje od ostalih suvlasnika, u skladu s građevinskim propisima promijeniti namjenu svog posebnog dijela, ali promjena ne smije prouzročiti oštećenje zgrade i drugih dijelova nekretnine, a ni povredu onih interesa ostalih suvlasnika koji zaslužuju zaštitu. Osobito ne smije prouzročiti povredu vanjskoga izgleda zgrade, ni opasnost za sigurnost osoba, zgrade ili drugih stvari, a ako bi za promjenu bilo potrebno zadrijeti u zajedničke dijelove nekretnine za prenamjenu je potreban pristanak ostalih suvlasnika.

Budući da se kod vlasništva posebnog dijela nekretnina radi o suživotu više osoba i obitelji u jednoj zgradi, postupci i navike jednih intenzivnije nego kod drugih oblika stanovanja utječu na kvalitetu života ostalih stanara. Česta je pojava da se prostornim planovima u područjima stambene namjene omogućava gradnja stambeno poslovnih građevina u kojima se uz stanove na gornjim etažama, u pravilu u prizemlju, nalaze poslovni prostori. ${ }^{69} \mathrm{U}$ slučajevima prenamjene čisto stambenih u stambeno poslovne građevine ili promjene namjene djelatnosti u poslovnom prostoru stambeno poslovnih građevina zna doći do protivljenja stanara koji nisu uvijek skloni da se u zgradi u kojoj žive, obavlja djelatnost koju bi vlasnik posebnog dijela želio obavljati.

Od navedenih uvjeta za prenamjenu pripisanih Zakonom o prostornom uređenju i Zakonom o vlasništvu i drugim stvarnim pravima, najšire polja tumačenja ostavlja zaštita "onih interesa ostalih suvlasnika koji zaslužuju zaštitu". Smatramo da se taj uvjet ne smije tumačiti ekstenzivno na štetu vlasnika koji traži prenamjenu, već ga se mora ostaviti više kao korektiv kada bi prenamjena znatno štetila interesima ostalih suvlasnika, na način da bi im bitno umanjila kvalitetu života. Smatramo da u prilog tog stava govori i odredba ${ }^{70}$ koja propisuje mogućnost isključenja suvlasnika iz suvlasničke zajednice, ako posebni dio nekretnine rabi na način koji znatno ide na štetu ostalih suvlasnika, jer ako se suvlasnika može isključiti zbog načina korištenja posebnog dijela, ne treba mu ni dopustiti da ga prenamijeni za korištenje koje će biti razlog za isključenje. Izvan toga bi svaki suvlasnik morao biti svjestan koje je djelatnosti prema prostornom planu dozvoljeno obavljati u zgradi koje je suvlasnik i da je uvijek moguće da će netko zatražiti prenamjenu. Stoga se ne bi smio pozivati na nikakva stečena prava, čak štoviše, svakom bi trebalo priznati da ima legitimno očekivanje da će uz uvjet da ne zadire u zajedničke dijelove i znatno ne šteti interesima ostalih suvlasnika moći izvršiti prenamjenu u skladu s prostornim planom.

\section{ZAŠTITA PRAVA VLASNIŠTVA U POSTUPCIMA UTVRĐENJA GRA円EVNE ČESTICE}

Rješenje o utvrđivanju građevne čestice donosi se: 1. ako za postojeću građevinu nije utvrđena građevna čestica, odnosno zemljište nužno za redovitu uporabu građevine, 2. kada je obveza utvrđivanja građevne čestice odnosno zemljišta nužnog za redovnu uporabu građevine propisana posebnim zakonom i 3. kada vlasnik građevine želi promijeniti oblik i veličinu građevne čestice. ${ }^{71} \mathrm{Na}$ temelju rješenja

69 Npr. čl. 11. UPU Gornja Drenova.

70 Čl. 98. st. 3. alineja 2. ZV-a.

71 Čl. 157. ZPU-a. 
utvrđenju građevne čestice u katastarskom operatu provodi se parcelacija, odnosno osnivanje nove ili novih katastarskih čestica. ${ }^{72}$

ZPU-om nisu detaljnije razrađeni uvjeti pod kojima se utvrđuje građevna čestica, osim da se građevna čestica određuje u skladu s prostornim planom. Ako to nije moguće tada u skladu s pravilima struke, vodeći računa da se građevna čestica utvrdi tako da oblikom i veličinom omogućava redovitu uporabu građevine. Od navedenog pravila propisane su još dvije iznimke: kada vlasnik građevine želi promijeniti oblik i veličinu građevne čestice na kojoj je postojeća zgrada u skladu s prostornim planom, građevna čestica se određuje u skladu s prostornim planom, te da se građevna čestica zgrade koja ima više samostalnih uporabnih cjelina, a s više svojih strana graniči s površinom javne namjene, određuje se kao zemljište koje je ispod te zgrade. ${ }^{73}$

Isto tako, ZPU-om je propisano da se rješenje o utvrđenju građevne čestice donosi na zahtjev stranke ili po službenoj dužnosti, ali nije propisano tko sve može biti strankom u postupku. Tu treba primijeniti opća pravila ZUP-a i strankom uz podnositelja zahtjeva priznati svakog u čija se prava i interese u postupku može dirati, ${ }^{74}$ a pritom i uvijek vlasnika zemljišta koje bi građevna čestica mogla obuhvatiti.

Analizu zaštite prava vlasništva u postupcima utvrđenja građevne čestice ograničit ćemo na pitanje može li se građevna čestica utvrditi neovisno pa i suprotno od volje vlasnika zemljišta koje je obuhvaćeno građevnom česticom. Smatramo da ne može, iako u praksi ima i suprotnih stajališta.

Građevna čestica je u pravilu katastarska čestica čiji je oblik, smještaj u prostoru i veličina u skladu s prostornim planom. ${ }^{75}$ Podsjećamo da je katastarska čestica dio zemljine površine koja je u katastru zemljišta označena posebnim brojem i omeđena granicama koje određuju pravni odnosi, a sastoji se od zemljišta i svega što je sa zemljištem trajno spojeno na površini ili ispod nje $e^{76}$, a rekli smo i da je rješenje o utvrđenju građevne čestice temelj za provedbu parcelacije u katastarskom operatu. Budući da je perspektiva i smisao građevne čestice da u katastru zemljišta bude formirana kao jedna katastarska čestica ili više katastarskih čestica koje čine jedno zemljišnoknjižno tijelo i da kao takva bude označena jednim nositeljem prava vlasništva, odnosno eventualno s više njih prema pravilima stvarnog prava o vlasništvu više osoba na istoj stvari, smatramo da utvrđenje građevne čestice apsolutno mora ovisiti o volji vlasnika zemljišta, odnosno je li vlasnik suglasan da dio njegovog zemljišta postane dijelom katastarske čestice u vlasništvu druge osobe i da na nju prenese vlasništvo tog dijela zemljišta. Ako vlasnik nije voljan prenijeti dio zemljišta na drugu osobu radi formiranja katastarske čestice, nema smisla niti da se dopusti formiranje građevine čestice, jer se ona u perspektivi neće moći provesti u katastru zemljišta i zemljišnim knjigama. Smatramo da bi u postupcima utvrđenja građevne čestice trebalo analogno primijeniti pravila o pravnom interesu za izdavanje

72 Čl. 160. ZPU-a, čl. 53. Zakona o državnoj izmjeri i katastru nekretnina, NN br. 16/07., 152/08., 124/10., 56/13., 121/16., 9/17., dalje: ZDIKN.

73 Čl. 159. ZPU-a.

74 Čl. 4. ZUP-a.

75 Čl. 3. st. 1.t. 3. ZPU-a.

76 Čl. 20. ZDIKN-a, čl. 2. Zakona o zemljišnim knjigama, NN br. 91/96., 68/98., 137/99., 114/01., 100/04., 107/07., 152/08., 126/10., 55/13., 60/13., 108/17., čl. 9. ZV-a. 
lokacijske dozvole, koje se kao što smo ranije naveli, u upravnosudskoj praksi rodilo i prije nego je propisano zakonom ${ }^{77}$, tako da bi pravni interes za utvrđenje građevne čestice imala osoba za koju je realno očekivati da će građevnu česticu moći formirati u katastru zemljišta i zemljišnim knjigama.

\section{ZAKLJUČ $A K$}

Pitanje u kojoj mjeri i kojem opsegu se u postupcima provedbe prostornih planova štite prava i interesi vlasnika zemljišta posebno dolazi do izražaja u postupcima izdavanja lokacijskih dozvola za gradnju prometnica, komunalnih građevina, plinovoda i sličnih infrastrukturnih objekata, zbog velike slobode i raspona unutar kojeg je u skladu s prostornoplanskom dokumentacijom u postupku izdavanja lokacijske dozvole moguće prikazati građevnu česticu i smještaj građevine. Primjenom pravnih shvaćanja Europskog suda za ljudska prava o pravu na mirno uživanje vlasništva, dolazi se do zaključka da se u postupcima izdavanja lokacijskih dozvola radi izgradnje infrastrukturnih objekata moraju razmotriti svi prigovori stranaka te da se smještaj i položaj građevine mora odrediti tako da se u okvirima važeće prostornoplanske dokumentacije postigne poštena ravnoteža između zahtjeva općega interesa zajednice i zahtjeva za zaštitom temeljnih prava pojedinca. To ne znači da se zahtjevima vlasnika zemljišta mora udovoljiti, već da se mora postići ravnoteža kojom će se maksimalno koliko je moguće udovoljiti interesima svih zainteresiranih subjekata, uzimajući u obzir da se prednost uvijek mora treba dati javnom pred pojedinačnim interesom. Ako sudska praksa zauzme suprotno stajalište, odnosno da se u postupcima provedbe prostornih planova utvrđuje isključivo usklađenost $\mathrm{s}$ prostornoplanskom dokumentacijom i da mjesta drugoj zaštiti vlasničkih prava nema, nema smisla ni potrebe niti da se u tim postupcima vlasnika nekretnine, a i nositelja drugih stvarnih prava, određuje strankom.

Prava i interesi vlasnika nekretnine koja graniči s nekretninom iz zahvata štite se i priznaju najsnažnije ako je vlasništvo na susjednoj nekretnini povezano s pravom služnosti na nekretnini iz zahvata, odnosno ako je susjedna nekretnina u odnosu na nekretninu iz zahvata povlasna nekretnina, u kojem slučaju će investitor morati ustuknuti pred pravima vlasnika susjedne nekretnine. U određenoj mjeri se prava i interesi vlasnika susjedne nekretnine štite i kada ostvarivanje lokacijskih uvjeta za planiranu građevinu u skladu s prostornim planom može značiti povredu postojećih zakonito utvrđenih lokacijskih uvjeta na susjednoj građevini, gdje se treba naći ravnoteža sukobljenih prava i interesa i pokušati im maksimalno koliko je moguće udovoljiti, imajući u vidu koji interes u konkretnom slučaju prevladava. Izvan toga, vlasnici susjednih nekretnina u svezi s uvjetima stanovanja, kao što su pogled, privatnost, tišina, mir i slično, nemaju i ne mogu steći nikakva prava na temelju kojih bi druge mogli spriječiti da pod istim uvjetima grade u skladu s prostornoplanskom dokumentacijom i mjerodavnim propisima.

Promjenu namjene građevine treba dopustiti ako je u skladu s prostornim planom i lokacijskim uvjetima, Ako je riječ o posebnom dijelu nekretnine i pod

77 Vidi supra, str. 10. 
uvjetom da se bez pristanka ostalih suvlasnika ne zadire u zajedničke dijelove i ne šteti onim interesima ostalih suvlasnika koji zaslužuju zaštitu. Posljednji uvjet ne smije se tumačiti ekstenzivno na štetu vlasnika koji traži prenamjenu, već ga se mora ostaviti više kao korektiv kada bi prenamjena u znatnoj mjeri štetila interesima ostalih suvlasnika, na način da bi im bitno umanjila kvalitetu života.

Budući da je perspektiva i smisao građevne čestice da u katastru zemljišta bude formirana kao jedna katastarska čestica i da je kao takva označena jednim nositeljem prava vlasništva, utvrđenje građevne čestice mora biti uvjetovano suglasnošću vlasnika. Ako vlasnik nije voljan prenijeti dio zemljišta na drugu osobu radi formiranja katastarske čestice, nema smisla niti da se dopusti formiranje građevine čestice, jer se ona neće moći provesti u katastru zemljišta i zemljišnim knjigama. 


\section{LITERATURA}

Radovi

1. Berlengi Fellner, Ana, Zaštita prava stranaka u postupcima prema propisima o gradnji, Gradnja i prostorno uređenje, legalizacija, koncesije i izvlaštenje, Zagreb, Novi informator, 2017.

2. Borković, Ivo, Upravno pravo, Zagreb, Narodne novine, 2002.

3. Brežanski, Jasna, Zaštita prava vlasništva, Rijeka, ZPFR, vol. 23, br. 1, 2002.

4. Gavella, Nikola, Josipović, Tatjana, Gliha, Igor, Belaj, Vlado, Stipković, Zlatan, Stvarno pravo, Zagreb, Narodne novine, 2007.

5. Gavella, Nikola, Alinčić, Mira, Klarić, Petar, Sajko, Krešimir, Tumbri, Tanja, Stipković, Zlatan, Josipović, Tatjana, Gliha, Igor, Matanovac, Romana, Ernst, Hano, Teorijske osnove građanskog prava - Građansko pravo i pripadnost hrvatskog pravnog poretka kontinentalnoeuropskom pravnom krugu, Zagreb, Pravni fakultet, 2005.

6. Gavella, Nikola, Ograničenja prava vlasništva, Rijeka, ZPFR, vol. 19, br. 2, 1998.

7. Jelčić, Olga, Tužbe radi zaštite prava vlasništva, www.vsrh.hr, 2001., 29. prosinca 2017.

8. Klarić, Petar, Vedriš Martin, Građansko pravo, Zagreb, Narodne novine, 2006.

9. Krpan, Ljudevit, Značenje prometne infrastrukture u prostornom planiranju, Prostorno planiranje u Primorsko-goranskoj županiji: povijest-stanje-perspektive, Rijeka, Zavod za prostorno planiranje Primorsko-goranske županije, 2011.

10. Marinović-Uzelac, Ante, Prostorno planiranje, Zagreb, Dom i svijet, 2001.

11. Mrak-Taritaš, Ana, Analiza stanja u prostoru i normativnom uređenju kao podloga za izradu novog zakona o prostornom uređenju i gradnji, Osamnaesti forum poslovanja nekretninama, Zagreb, Hrvatska gospodarska komora, 2012.

12. Mrak-Taritaš Ana, Lokacijska dozvola od prostornog plana do upravnog akta, Četrnaesti forum poslovanja nekretninama, Zagreb, Hrvatska gospodarska komora, 2009.

13. Omejec, Jasna, Konvencija za zaštitu ljudskih prava i temeljnih sloboda u praksi europskog suda za ljudska prava - Strasbourški acquis, Zagreb, Novi informator, 2013.

14. Omejec, Jasna, Ustavno i konvencijsko jamstvo prava vlasništva, Liber amicorum in honorem Jadranko Crnić, Zagreb, Novi informator, 2009.

15. Poropat, Amorino, Identifikacija parcele prometnice u naselju, Zagreb, Glasilo Hrvatske komore arhitekata i inženjera u graditeljstvu br. 18, 2005.

16. Žagar, Antun, Prostorno uređenje i gradnja u upravnosudskoj praksi, Aktualnosti upravne prakse i upravnog sudovanja - 2017., Zagreb, Inženjerski biro, 2017.

Zbornici sudske prakse

1. Upravni sud Republike Hrvatske, Zbornik odluka 1977.-2007., Zagreb, Narodne novine, 2007.

2. Visoki upravni sud Republike Hrvatske, Zbornik odluka 1977.-2017., Zagreb, Narodne novine, 2017.

Propisi

1. Konvencija za zaštitu ljudskih prava i temeljnih sloboda, NN MU, br. 18/97, 14/02., 13/03., 9/05., 1/06., 2/10., 13/17.

2. Ustav Republike Hrvatske, NN, br. 56/90., 135/97., 113/00., 28/01., 76/10., 5/14.

3. Zakon o prostornom uređenju, NN, br. 153/13., 65/17.

4. Zakon o prostornom uređenju, NN, br. 30/94.

5. Zakon o prostornom uređenju i gradnji, NN, br. 76/07. 
6. Zakon o prostornom uređenju i korištenju građevinskog zemljišta, NN, br. 14/73.

7. Zakon o prostornom planiranju i uređenju prostora, NN, br. 54/80.

8. Zakon o gradnji, NN, br. 153/13., 20/17.

9. Zakon o općem upravnom postupku, NN, br. 47/09.

10. Zakon o vlasništvu i drugim stvarnim pravima, NN, br. 91/96., 68/98., 137/99., 22/00., 73/00., 114/01., 79/06., 141/06., 146/08., 38/09., 153/09., 90/10., 143/12., 152/14.

11. Zakon o zemljišnim knjigama, NN, br. 91/96., 68/98., 137/99., 114/01., 100/04., 107/07., 152/08., 126/10., 55/13., 60/13., 108/17.

12. Zakon o državnoj izmjeri i katastru nekretnina, NN, br. 16/07., 152/08., 124/10., 56/13., 121/16., 9/17.

13. Zakon o izvlaštenju i određivanju naknade, $\mathrm{NN}$ br. 74/14., 69/17.

14. Zakon o izvlaštenju, NN, br. 9/94., 35/94., 112/00., 114/01., 79/06., 45/11., 34/12.

15. Pravilnik o sadržaju, mjerilima kartografskih prikaza, obveznim prostornim pokazateljima i standardu elaborata prostornih planova, NN, br. 106/98., 39/04., 45/04., 163/04., 153/13.,

16. Pravilnik o jednostavnim i drugim građevinama i radovima, NN, br. 112/17.

17. Pravilnik o parcelacijskim i drugim geodetskim elaboratima, NN, br. 86/07, 25/09, $148 / 09$.

Prostorni planovi

1. Prostorni plan uređenja Grada Pule, SN Grada Pule br. 12/06., 12/12., 5/14., 7/15., 10/15- pročišćeni tekst, 5/16., 2/17., 5/17.

2. Generalni urbanistički plan grada Rijeke, SN Primorsko-goranske županije br. 7/07., 14/13., 8/14., 3/17.

3. Generalni urbanistički plan uređenja Grada Pule, SN Grada Pule br. 5a/08., 12/12., 5/14., 10/14., 13/14., 7/15., 2/17. i 5/17.

4. Urbanistički plan uređenja gradskog područja Gornja Drenova, SN Primorsko-goranske županije br. 21/10.

5. PUP-a "Stari Grad Pula”, SN, br. 6/92., 1/97., 11/07., 2/09. 


\title{
Antun Žagar*
}

\author{
Summary
}

\section{PROTECTION OF OWNERSHIP IN THE PROCEDURES FOR THE IMPLEMENTATION OF SPATIAL PLANS}

Spatial planning is introduced into legal life through the adoption of spatial plans and then by the issuance of individual acts for the implementation of spatial plans: location or building permits, permits for change of purpose of building and acts for determination of building particle. Recently there have been some questions in the spatial plans implementation process, which did not have any response until then that would be in line with the contemporary understanding of the right of ownership and the right to peaceful enjoyment of ownership. The aim of this paper is to try to answer the question of whether the rights and interests of land owners should be protected in the procedures for the implementation of spatial plans, in the first place in the procedures for issuing location permits for the construction of infrastructure facilities, or any request of the applicant consistent with spatial document documentation must be accepted. It is concluded that, while respecting the goals and principles of spatial planning and the principle of social ownership of the property, the rights and interests of the owner are to a certain extent protected.

Keywords: protection of ownership, spatial planning, spatial plans, acts for the implementation of spatial plans, location permit.

Zussamenfassung

\section{SCHUTZ DES EIGENTUMS BEIM VOLLZUG DER RAUMORDNUNGSPLÄNE}

Die Raumordnung wird in die Rechtssphäre durch die Erlassung von Raumordnungsplänen eingeführt. Danach folgt die Einholung der für den Vollzug der Raumordnungspläne notwendigen Dokumente: Baureiferklärung, Baugenehmigung, Nutzungsänderungsgenehmigung, Baulandbeschluss und Vermessungselaborat. Neulich sind beim Vollzug der Raumordnungspläne manche Fragen aufgetaucht, auf die es bisher keine Antworten gab, beziehungsweise, es gab keine für die moderne Wahrnehmung des Eigentumsrechts und der friedlichen Nutznießung des Eigentums angemessenen Antworten. Diese Arbeit versucht die Antwort auf die Frage zu geben, ob man beim Vollzug der Raumordnungspläne, vor allem bei der Einholung von

* Antun Žagar, Judge of the Administrative Court in Rijeka; antun.zagar@usri.pravosudje.hr. 
Baugenehmigungen, die Rechte und Interessen der Eigentümer schützen kann, oder ob man jeden Antrag, der im Einklang mit der Raumordnungsdokumentation ist, annehmen muss. Abschließend wird betont, dass man durch die Berücksichtigung der Ziele und Grundsätze der Raumordnung sowie auch des Grundsatzes, dass Eigentum ein soziales Phänomen ist, die Rechte und Interessen der Eigentümer gewissermaßen schützen kann.

Schlüsselwörter: Schutz der Eigentumsrechte, Raumordnung, Raumordnungspläne, die für den Vollzug der Raumordnungspläne notwendigen Dokumente, Baugenehmigung.

Riassunto

\section{LA TUTELA DEL DIRITTO DI PROPRIETÀ NEI PROCEDIMENTI DI REALIZZAZIONE DEI PIANI TERRITORIALI}

La pianificazione del territorio è un'attività multidisciplinare che entra nella vita giuridica mediante l'emanazione dei piani territoriali ed in seguito mediante assoggettamento di un concreto rapporto giuridico alla norma definita nel piano territoriale, ossia mediante il rilascio di singoli atti per la realizzazione del piano territoriale: licenze edilizie, licenze per il cambiamento d'uso dell'edificio, provvedimenti di accertamento catastale e certificati di elaborati delle particelle. In tempi recenti nei procedimenti di realizzazione dei piani territoriali sono emerse alcune questioni che fino ad ora sono rimaste irrisolte; in quanto non si rinvenivano risposte che fossero conformi alla concezione contemporanea del diritto di proprietà ed il diritto al pacifico godimento del bene che ne deriva. L'oggetto del presente lavoro è quello di cercare di dare una risposta all'interrogativo se nei procedimenti di realizzazione dei piani territoriali, anzi tutto nei procedimenti di rilascio delle licenze per la costruzione delle infrastrutture, vi sia spazio per la tutela dei diritti e degli interessi del proprietario del fondo oppure si debba in tali procedimenti accogliere qualsiasi richiesta che sia conforme alla documentazione prevista nel piano. Si giunge alla conclusione che, rispettando i fini ed i principi della pianificazione del territorio ed anche il principio della funzione sociale della proprietà, i diritti e gli interessi del proprietario sono in una determinata misura tutelati.

Parole chiave: tutela del diritto di proprietà, pianificazione del territorio, piani territoriali, atti di attuazione dei piani territoriali, licenza edilizia. 